\title{
Metastatic Lung Small Cell Carcinoma
}

National Cancer Institute

\section{Source}

National Cancer Institute. Metastatic Lung Small Cell Carcinoma. NCI Thesaurus. Code C156095.

A small cell carcinoma that arises from the lung and has metastasized to another anatomic site. 